\begin{tabular}{|c|c|}
\hline $\begin{array}{l}\text { Chemistry of } \\
\text { Metals and Allovs }\end{array}$ & 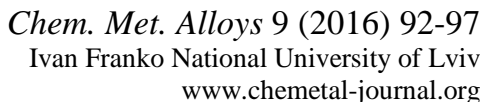 \\
\hline
\end{tabular}

\title{
The solubility of silicon in Li-Sn binary phases
}

\author{
Ivan TARASIUK ${ }^{1} *$ \\ ${ }^{1}$ Department of Inorganic Chemistry, Ivan Franko National University of Lviv, \\ Kyryla i Mefodiya St. 6, UA-79005 Lviv, Ukraine \\ * Corresponding author.Tel.: +380-32-2394506; e-mail: tarasiuk.i@gmail.com
}

Received June 17, 2016; accepted June 29, 2016; available on-line November 7, 2016

\begin{abstract}
During an investigation of the interaction of the components in the $\mathrm{Li}-\mathrm{Sn}-\mathrm{Si}$ system, the existence of seven binary compounds was confirmed in the Li-Sn system by means of X-ray powder diffraction. A continuous series of solid solutions was found between the $L_{17} S_{1}$ and $L_{17} S_{i}$ binary intermetallides with $L_{17} P_{1} b_{4}$-type structure. The cell parameters within the solid solutions change approximately according to Vegard's law $\left(\mathrm{Li}_{17} \mathrm{Sn}_{4-x} \mathrm{Si}_{x}(x=0-4), a=1.9714(1)-1.8718(1) \mathrm{nm}\right)$. The variation of the lattice parameters within the limited solid solutions based on $\mathrm{LiSn}$ (up to 10 at.\%) and $\mathrm{Li}_{7} \mathrm{Sn}_{3}$ (up to 5 at.\%) binary compounds was also determined.
\end{abstract}

\section{Crystal structure / X-ray powder diffraction / Binary compound / Solid solution}

\section{Introduction}

One of the disadvantages of the widely used carbonbased anode materials for $\mathrm{Li}$-ion batteries is the low $\mathrm{Li}$ charge density. Sn-based alloys have high theoretical charge densities, which allows considering them as possible candidates for replacing $\mathrm{LiC}_{6}$ [1]. Addition of small amounts of silicon increases the specific capacity but does not cause any large volume expansion upon lithiation as is the case for pure Si. The Li-Sn phase diagram has been studied based on measurements of thermo-chemical and thermophysical properties of alloys [2-5]. The reported phase diagrams are in good agreement with each other, although uncertainties remain in the Li-rich part at high temperatures. The phase diagram and thermochemical data were summarized [6]. Several thermodynamic descriptions of the Li-Sn system have been performed [5,7-9]. Using differential thermal analysis, powder X-ray diffraction technique and CALPHAD method, the existence of seven binary compounds, most of which were discovered in the 1970s, was confirmed [9].

The compounds $\mathrm{Li}_{7} \mathrm{Sn}_{2}$ (structure type (ST) $\mathrm{Li}_{7} \mathrm{Ge}_{2}$, space group (SG) Cmmm) [10] and LiSn (own ST, SG $P 2 / m$ ) [11] melt congruently at 1056 and $759 \mathrm{~K}$, respectively. The compounds $\mathrm{Li}_{13} \mathrm{Sn}_{5}$ (own ST, SG $P-3 m 1)$ [12], $\mathrm{Li}_{5} \mathrm{Sn}_{2}\left(\mathrm{ST} \mathrm{Mo}_{2} \mathrm{~B}_{5}, \mathrm{SG} R-3 m\right)$ [13], $\mathrm{Li}_{7} \mathrm{Sn}_{3}$ (own ST, SG $P 2_{1} / m$ ) [14], and $\mathrm{Li}_{2} \mathrm{Sn}_{5}$ (ST $\mathrm{Mn}_{2} \mathrm{Hg}_{5}$, SG P4/mbm) [15] form via peritectic reactions at 997, 971, 782, and $600 \mathrm{~K}$, respectively. The discussions mainly concern the Li-richest phase with a large unit cell. Its composition was first reported as $\mathrm{Li}_{22} \mathrm{Sn}_{5}\left(\mathrm{ST}_{\mathrm{Li}_{22}} \mathrm{~Pb}_{5}\right.$, SG F23) [16], then $\mathrm{Li}_{21} \mathrm{Sn}_{5}$ (ST $\mathrm{Li}_{21} \mathrm{Si}_{5}$, SG $F-43 m$ ) was proposed [17]. Based on detailed studies by X-ray single-crystal and neutron powder diffraction, the composition was corrected to $\mathrm{Li}_{17} \mathrm{Sn}_{4}$ (own ST [18] or $\mathrm{ST}^{2} \mathrm{Li}_{17} \mathrm{~Pb}_{4}$ [19], SG $F-43 m$ ). This phase melts congruently at $1031 \mathrm{~K}$.

To the best of my knowledge, there is hardly any information in the literature about compounds in systems containing two $p$-elements of group IV and lithium. Only a continuous series of solid solutions $\mathrm{Li}_{17} \mathrm{Si}_{4-x} \mathrm{Ge}_{x}\left(x=0-4\right.$, ST $\mathrm{Li}_{17} \mathrm{~Pb}_{4}$, SG $\left.F-43 m\right)$ has been reported [20]. The best investigated related ternary systems are those containing $\mathrm{Li}$ and $p$-elements of groups III and IV (in particular systems with aluminium), followed by systems with $p$-elements of groups III and V. As part of an investigation of the interaction between the components in the $\mathrm{Li}-\mathrm{Sn}-\mathrm{Si}$ system, the possible solubility of $\mathrm{Si}$ in $\mathrm{Li}-\mathrm{Sn}$ binary compounds was studied in the present work.

\section{Experimental}

Alloys were made by two methods of synthesis, using the following starting materials: lithium (nominal purity $99.9 \mathrm{wt} \%$ ), silicon (99.99 wt.\%), and tin (99.99 wt.\%). In the first case mixtures of the components were melted by arc melting on a watercooled copper hearth in purified argon atmosphere, using titanium getter and a tungsten electrode. As the alloys include a volatile element $(\mathrm{Li})$, the latter was added in excess, depending on the expected content in the alloy, but no more than $5 \%$. The composition of 
the alloys was controlled by comparing the weight before and after melting, limited to $3 \%$. The alloys were kept under inert oil. In the second case, stoichiometric quantities of the components were heated to $1380 \mathrm{~K}$ in sealed tantalum crucibles with intensive shaking during the process. The samples were held for $10 \mathrm{~min}$ and then slowly cooled down to room temperature. After melting the total weight loss was less than $2 \%$.

Phase analysis of the samples was carried out by X-ray powder diffraction, using DRON-2.0M (Fe $K_{\alpha^{-}}$ radiation) and STOE STADI P (Mo $K_{\alpha}$-radiation, $0.02^{\circ}$ step size, $8 \mathrm{~s}$ counting time) diffractometers. Rietveld refinements of the powder diffraction data were performed by the FullProf program [21].

\section{Results and discussion}

The existence of seven binary compounds was confirmed in the Li-Sn system. According to the results, it was found that the binary compounds $\mathrm{Li}_{7} \mathrm{Sn}_{2}, \mathrm{Li}_{13} \mathrm{Sn}_{5}, \mathrm{Li}_{5} \mathrm{Sn}_{2}$, and $\mathrm{Li}_{2} \mathrm{Sn}_{5}$ do practically not dissolve silicon. The solid solutions based on the binary compounds $\mathrm{LiSn}$ and $\mathrm{Li}_{7} \mathrm{Sn}_{3}$ extend into the ternary $\mathrm{Li}-\mathrm{Sn}-\mathrm{Si}$ system up to 10 and 5 at.\% $\mathrm{Si}$, respectively. A continuous series of solid solutions was found between the compounds $\mathrm{Li}_{17} \mathrm{Sn}_{4}$ and $\mathrm{Li}_{17} \mathrm{Si}_{4}$. Similar interaction has been observed in the Li-Sn-V ternary system [22], where the LiSn, $\mathrm{Li}_{13} \mathrm{Sn}_{5}$, and $\mathrm{Li}_{7} \mathrm{Sn}_{2}$ binary compounds dissolve up to 5 at. $\% \mathrm{~V}$, and $\mathrm{Li}_{17} \mathrm{Sn}_{4}$ dissolves up to 10 at.\% $\mathrm{V}$.

In the lithium-rich ternary area a set of peaks was found on the diffraction patterns of the alloys. This set is characteristic of the binary compounds $\mathrm{Li}_{17} \mathrm{Sn}_{4}$ and $\mathrm{Li}_{17} \mathrm{Si}_{4}$. According to the results of a single-crystal $\mathrm{X}$-ray diffraction investigation [23], the composition $\mathrm{Li}_{17} \mathrm{Si}_{4}\left(\mathrm{ST} \mathrm{Li}_{17} \mathrm{~Pb}_{4}\right)$ was found to be more correct than $\mathrm{Li}_{21} \mathrm{Si}_{5}$ (own $\mathrm{ST}$ ), reported earlier [17]. Based on gradual deposition, the existence of a continuous series of solid solutions between the above-mentioned binary intermetallides was assumed. The crystal structure of the solid solution (Fig. 1) was refined by the powder diffraction method. The atom coordinates of the $\mathrm{Li}_{17} \mathrm{Sn}_{4}$ compound [19] were used as starting model for the refinement. The diffraction pattern of the $\mathrm{Li}_{81} \mathrm{Si}_{9.5} \mathrm{Sn}_{9.5}$ sample (STOE STADI P diffractometer, $\left.R_{\mathrm{B}}=0.104, R_{F}=0.149\right)$ is shown in Fig. 2. The lithium atoms occupy 13 independent positions in the structure and a statistical $\mathrm{Sn} / \mathrm{Si}$ mixture occupies another 4 sites. The coordination polyhedra of the atoms are Frank-Kasper and pseudo Frank-Kasper polyhedra, rhombic dodecahedra, icosahedra, and pentacapped trigonal prisms. The solid solution forms by mutual substitution of $\mathrm{Si}$ and $\mathrm{Sn}$ atoms. The cell parameters of different compositions of the solid solution $\mathrm{Li}_{17} \mathrm{Sn}_{4-x} \mathrm{Si}_{x}$ $(x=0-4)$ are listed in Table 1 . The change of the cell volume within the limits of the solid solution shows a slight negative deviation from Vegard's law (Fig. 3).
Table 1 Cell parameters of the $\mathrm{Li}_{17} \mathrm{Sn}_{4-x} \mathrm{Si}_{x}$ solid solution.

\begin{tabular}{c|c}
\hline Phase composition & $a, \mathrm{~nm}$ \\
\hline $\mathrm{Li}_{17} \mathrm{Si}_{4}$ & $1.8718(1)$ \\
$\mathrm{Li}_{17} \mathrm{Si}_{3} \mathrm{Sn}$ & $1.8882(3)$ \\
$\mathrm{Li}_{17} \mathrm{Si}_{2} \mathrm{Sn}_{2}$ & $1.9198(1)$ \\
$\mathrm{Li}_{17} \mathrm{SiSn}_{3}$ & $1.9457(2)$ \\
$\mathrm{Li}_{17} \mathrm{Sn}_{4}$ & $1.9714(1)$ \\
\hline
\end{tabular}

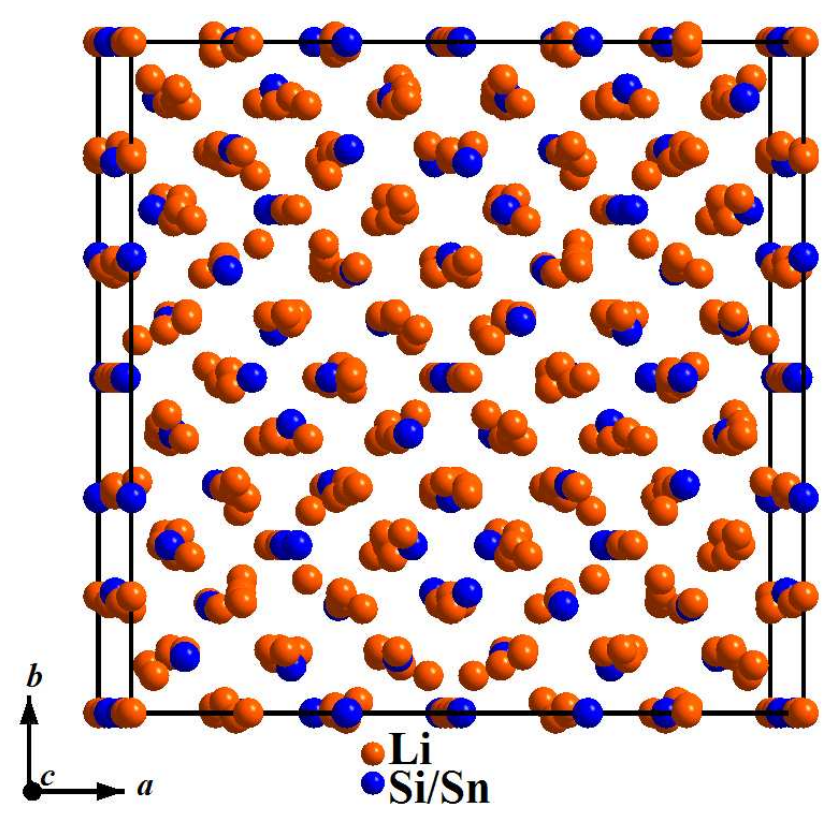

Fig. 1 Unit cell content in the structure of $\mathrm{Li}_{17} \mathrm{Sn}_{4-x} \mathrm{Si}_{x}(x=0-4)$.

The formation of a limited solid solution was observed based on the binary intermetallide LiSn (SG $P 2 / m, \quad a=0.51814(1), \quad b=0.31793(1)$, $\left.c=0.77626(3) \mathrm{nm}, \beta=104.82(1)^{\circ}, V=0.12362(2) \mathrm{nm}^{3}\right)$. Also this solid solution forms by partial substitution of $\mathrm{Si}$ atoms for $\mathrm{Sn}$ and extends to 10 at.\% $\mathrm{Si}$ in the ternary area. The crystal structure of the solid solution was refined by the powder diffraction method, using data obtained on the STOE STADI P diffractometer. The experimental and calculated diffraction patterns of the sample of composition $\mathrm{Li}_{50} \mathrm{Si}_{10} \mathrm{Sn}_{40}\left(\mathrm{LiSi}_{0.2} \mathrm{Sn}_{0.8}\right.$ content 92.4, Si 7.6 wt.\%) are shown in Fig. 4. The cell parameters of $\mathrm{LiSi}_{0.2} \mathrm{Sn}_{0.8}$ refined to $a=0.51738(2), \quad b=0.31722(1), \quad c=0.77428(2) \mathrm{nm}$, $\beta=104.98(1)^{\circ}, \quad V=0.12276(5) \mathrm{nm}^{3}$. The atom coordinates (reliability factors $R_{\mathrm{B}}=0.0658$ and $R_{F}=0.0476$ ) are given in Table 2. The interatomic distances have typical values for intermetallic compounds and are listed in Table 3. All the atoms in the structure have coordination polyhedra in the form of slightly distorted cuboctahedra $(\mathrm{CN}=12)$. A projection of the unit cell of $\mathrm{LiSi}_{x} \mathrm{Sn}_{1-x}(x=0-0.2)$ and the coordination polyhedra are shown in Fig. 5. 


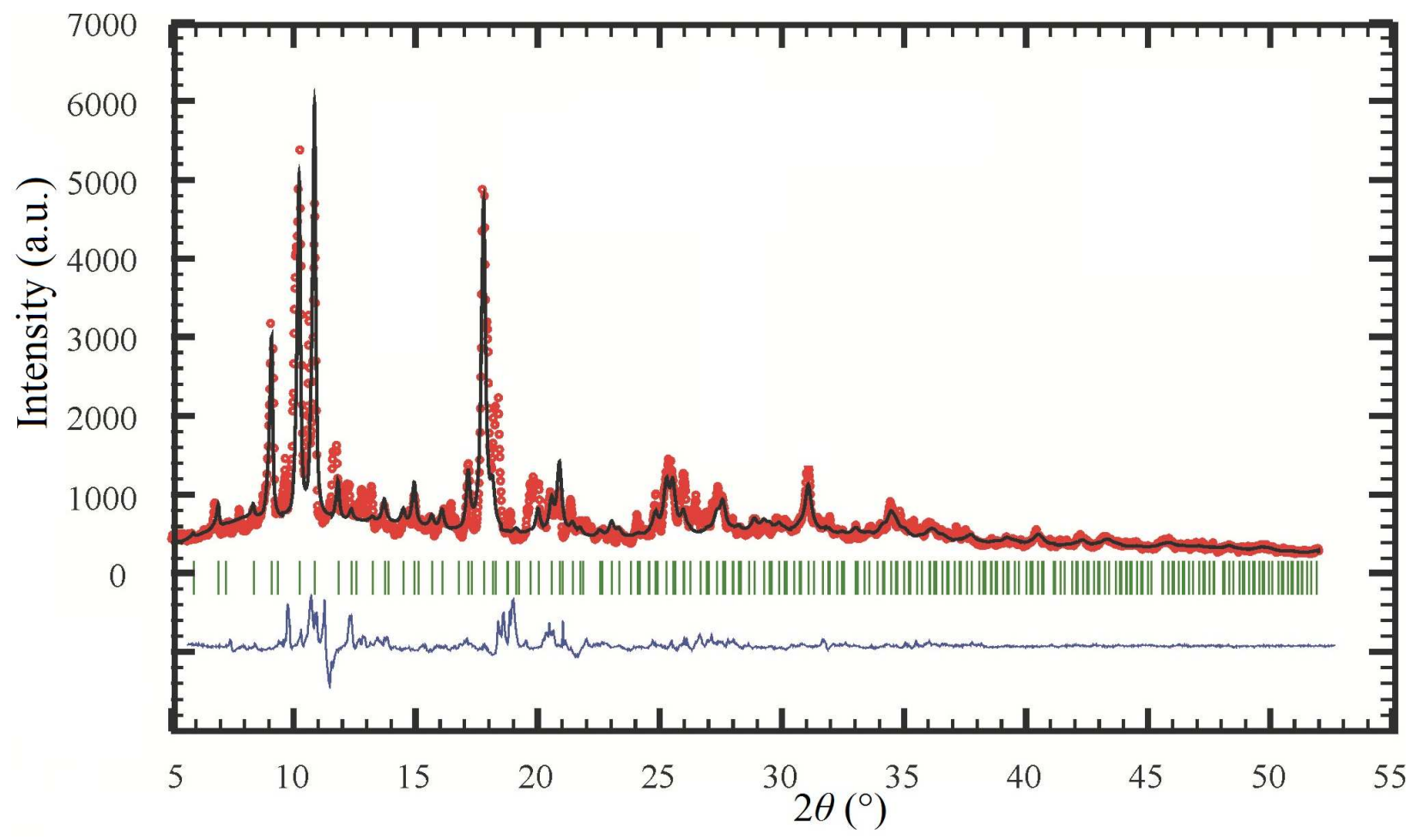

Fig. 2 Experimental (circles), calculated (continuous line) and difference between experimental and calculated (bottom) X-ray powder diffraction patterns of the sample $\mathrm{Li}_{81} \mathrm{Si}_{9.5} \mathrm{Sn}_{9.5}$.

Table 2 Atomic coordinates and isotropic displacement parameters of $\mathrm{LiSi}_{0.2} \mathrm{Sn}_{0.8}$.

\begin{tabular}{|c|c|c|c|c|c|c|}
\hline Site & Occupation & $\begin{array}{l}\text { Wyckoff } \\
\text { position }\end{array}$ & $x / a$ & $y / b$ & $z / c$ & $\mathrm{~B}_{\text {iso }} \times 10^{2}, \mathrm{~nm}^{2}$ \\
\hline Li1 & 1.00 & $2 n$ & $0.744(9)$ & $1 / 2$ & $0.689(8)$ & $2.9(3)$ \\
\hline $\mathrm{Li} 2$ & 1.00 & $1 e$ & $1 / 2$ & $1 / 2$ & 0 & $2.9(3)$ \\
\hline Sn,Si1 & $\begin{array}{l}0.82(7) \mathrm{Sn} \\
0.18(7) \mathrm{Si}\end{array}$ & $2 m$ & $0.7666(4)$ & 0 & $0.3398(4)$ & $1.2(1)$ \\
\hline $\mathrm{Sn}, \mathrm{Si} 2$ & $\begin{array}{l}0.79(6) \mathrm{Sn} \\
0.21(6) \mathrm{Si}\end{array}$ & $1 a$ & 0 & 0 & 0 & $1.1(1)$ \\
\hline
\end{tabular}

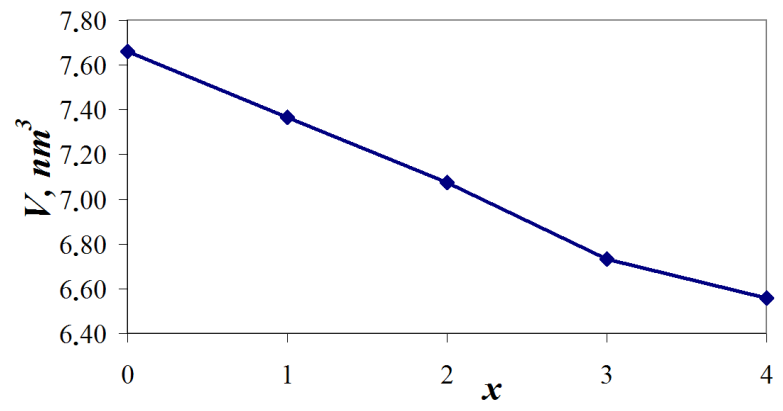

Fig. 3 Cell volume within the $\mathrm{Li}_{17} \mathrm{Sn}_{4-x} \mathrm{Si}_{x}$ $(x=0-4)$ solid solution.

The refined cell parameters of the binary phase $\mathrm{Li}_{7} \mathrm{Sn}_{3}$ in the alloy of composition $\mathrm{Li}_{70} \mathrm{Si}_{5} \mathrm{Sn}_{25}$ showed some difference with respect to the parameters of the binary compound (own ST, SG $P 2_{1} / m, a=0.8552$ (2), $b=0.4729(1), \quad c=0.9453(2) \mathrm{nm}, \quad \beta=105.96^{\circ}$, $V=0.3676(2) \mathrm{nm}^{3}$ ). This led to the conclusion that $\mathrm{Si}$ substitutes for a small amount of $\mathrm{Sn}$ and a solid solution based on the $\mathrm{Li}_{7} \mathrm{Sn}_{3}$ compound forms in the system. The cell parameters for the composition $\mathrm{Li}_{7} \mathrm{Si}_{0.5} \mathrm{Sn}_{2.5} \quad$ are $\quad a=0.8543(2), \quad b=0.4718(1)$, $c=0.9427(3) \mathrm{nm}, \beta=106.02(3)^{\circ}, V=0.3652(3) \mathrm{nm}^{3}$.

As it is known, the tendency to form solid solution is determined by the similarity of the interacting elements. The probability of formation of a solid solution increases when the crystal-chemical differences weaken. Thus, considering the similarity of silicon and tin, some substitution of $\mathrm{Si}$ for $\mathrm{Sn}$ in binary compounds is expected, and has been proven by the experiment. 


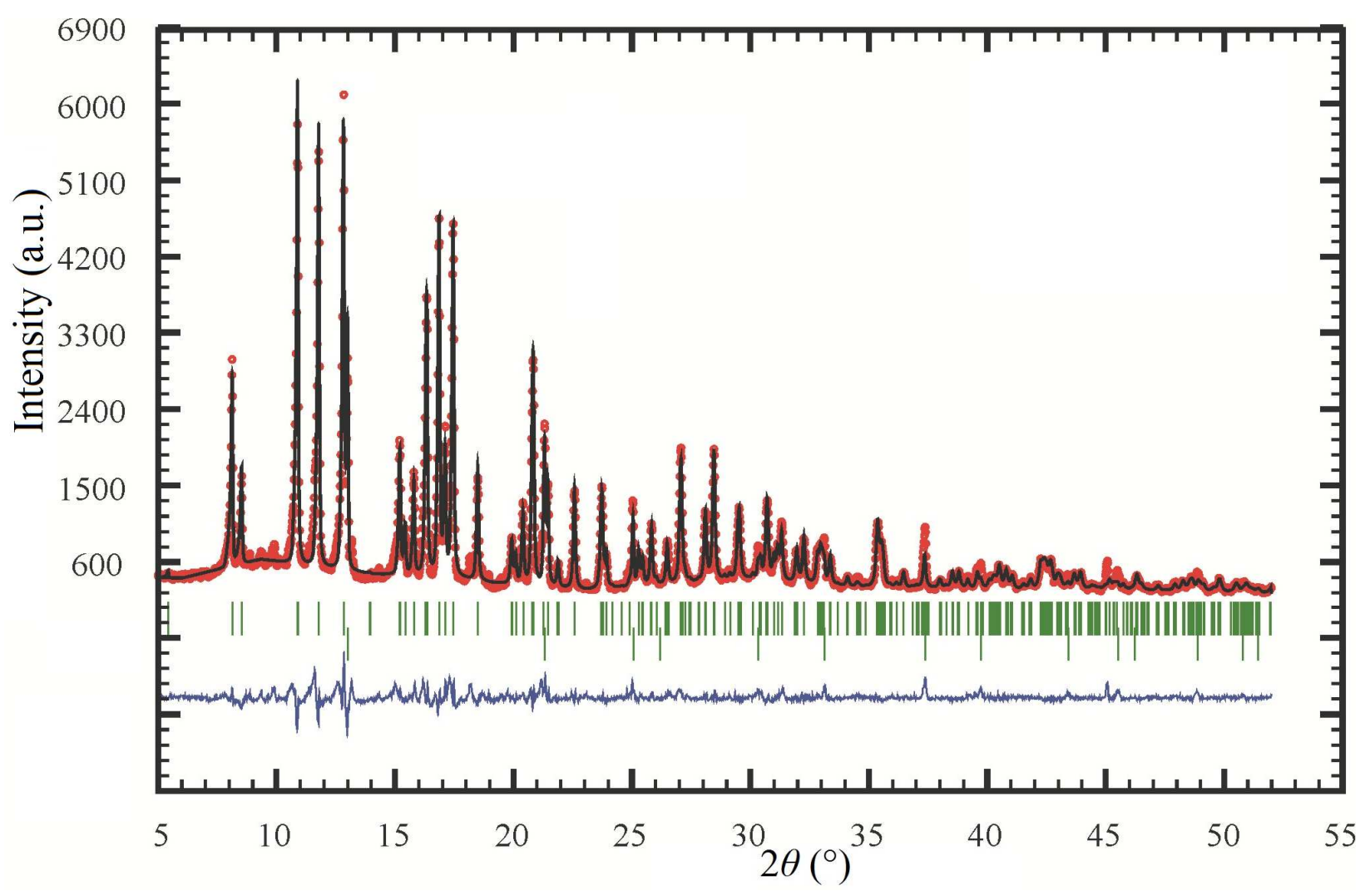

Fig. 4 Experimental (circles), calculated (continuous line) and difference between experimental and calculated (bottom) X-ray powder diffraction patterns for the sample $\mathrm{Li}_{50} \mathrm{Si}_{10} \mathrm{Sn}_{40}$.

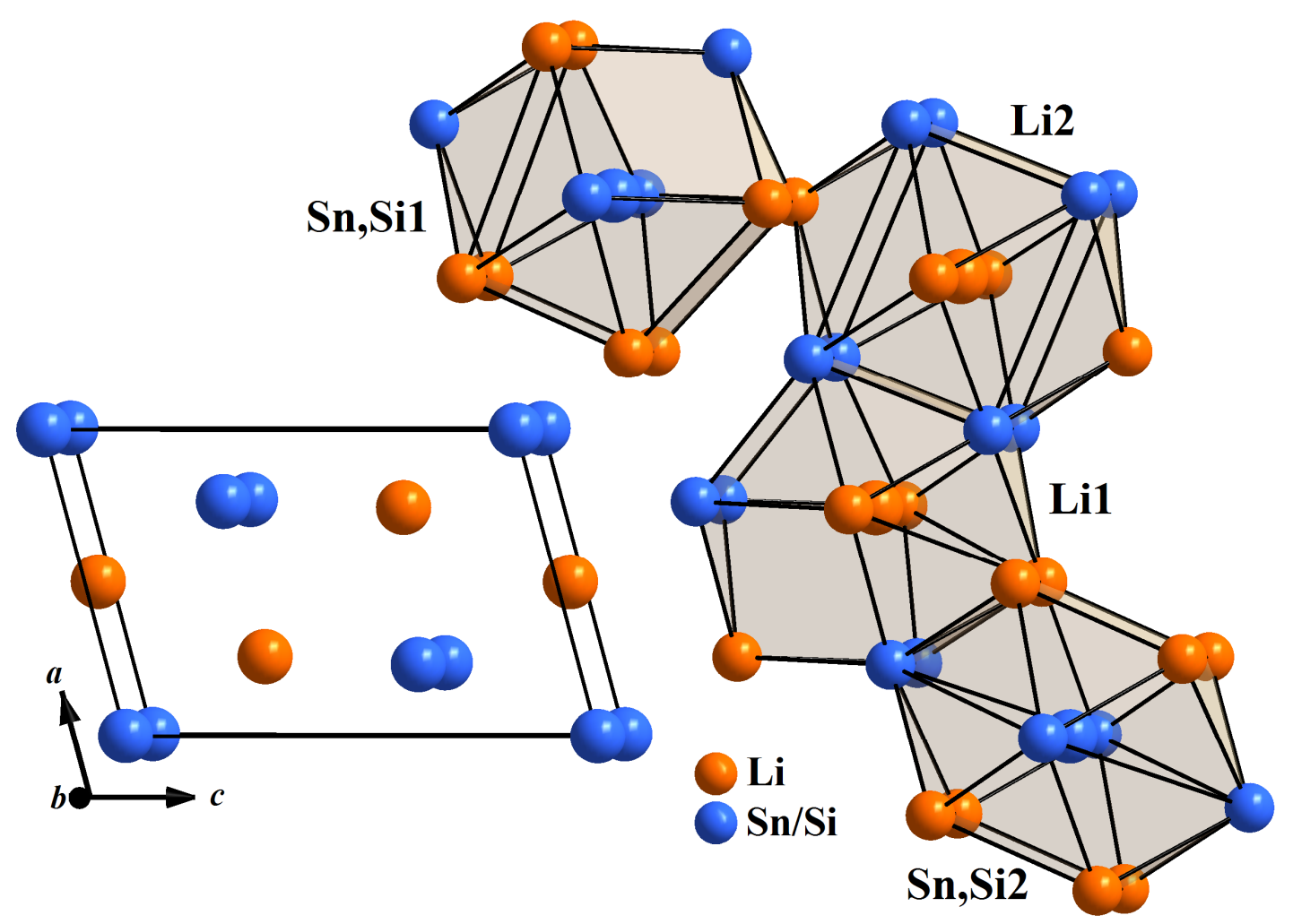

Fig. 5 Unit cell of the $\operatorname{LiSi}_{x} \mathrm{Sn}_{1-x}(x=0-0.2)$ solid solution and coordination polyhedra of the atoms. 
Table 3 Interatomic distances $(\delta)$ and coordination numbers $(\mathrm{CN})$ of the atoms in $\mathrm{LiSi}_{0.2} \mathrm{Sn}_{0.8}$.

\begin{tabular}{|c|c|c|c|}
\hline \multicolumn{2}{|c|}{ Atoms } & $\delta, \mathrm{nm}$ & $\mathrm{CN}$ \\
\hline Li1- & $\begin{array}{l}2(\mathrm{Sn}, \mathrm{Si}) \\
\mathrm{Li} 2 \\
2(\mathrm{Sn}, \mathrm{Si} 1) \\
2(\mathrm{Sn}, \mathrm{Si} 1) \\
2(\mathrm{Sn}, \mathrm{Si} 1) \\
2 \mathrm{Li} 1 \\
\mathrm{Li} 1\end{array}$ & $\begin{array}{l}0.2902 \\
0.2994 \\
0.3040 \\
0.3044 \\
0.3163 \\
0.3172 \\
0.3335\end{array}$ & 12 \\
\hline Li2- & $\begin{array}{l}2 \mathrm{Li} 1 \\
4(\mathrm{Sn}, \mathrm{Si} 2) \\
4(\mathrm{Sn}, \mathrm{Si} 1) \\
2 \mathrm{Li} 2\end{array}$ & $\begin{array}{l}0.2994 \\
0.3034 \\
0.3077 \\
0.3172 \\
\end{array}$ & 12 \\
\hline Sn,Si1- & $\begin{array}{l}\text { Sn,Si1 } \\
2 \mathrm{Li} 1 \\
2 \mathrm{Li} 1 \\
2 \mathrm{Li} 2 \\
2 \mathrm{Li} 1 \\
\mathrm{Sn}, \mathrm{Si} 2 \\
2(\mathrm{Sn}, \mathrm{Si} 1)\end{array}$ & $\begin{array}{l}0.2982 \\
0.3040 \\
0.3044 \\
0.3077 \\
0.3163 \\
0.3166 \\
0.3172\end{array}$ & 12 \\
\hline $\mathrm{Sn}, \mathrm{Si} 2-$ & $\begin{array}{l}4 \mathrm{Li} 1 \\
4 \mathrm{Li} 2 \\
2(\mathrm{Sn}, \mathrm{Si} 1) \\
2(\mathrm{Sn}, \mathrm{Si} 2)\end{array}$ & $\begin{array}{l}0.2902 \\
0.3034 \\
0.3166 \\
0.3172\end{array}$ & 12 \\
\hline
\end{tabular}

In the $\mathrm{Li}-X-X^{\prime}$ systems (where $X$ and $X^{\prime}$ are $p$-elements), the electronic structures of the interacting elements are not very different ( $s-p-p$ elements); Li has the largest metallic radius, but the difference is not significant. As a result, structure types with cuboctahedral $(\mathrm{CN}=12)$ coordination, or derivatives, are formed. Cuboctahedral coordination is observed in compounds where the ratio of the atom radii $r_{\mathrm{Li}} / r_{X}$ remains within the limits 1.10-1.00. In the investigated system $\mathrm{Li}-\mathrm{Sn}-\mathrm{Si}$, solid solutions based on the binary phases were found to exist. These phases also have cuboctahedral coordination and similar packing of atomic layers. Fig. 6 shows the structure of the $\mathrm{LiSi}_{x} \mathrm{Sn}_{1-x}(x=0-0.2)$ solid solution with alternating distorted square-mesh layers of $\mathrm{Li}$ atoms and $p$-elements.

\section{Acknowledgements}

Financial support of the Ministry of Education and Science of Ukraine is gratefully acknowledged (grant No. 0115U003257).

\section{References}

[1] A.R. Kamali, D.J. Fray, Rev. Adv. Mater. Sci. 27 (2011) 14-24.

[2] M.S. Foster, C.E. Crouthamel, S.E. Wood, J. Phys. Chem. 22 (1966) 3042-3045.

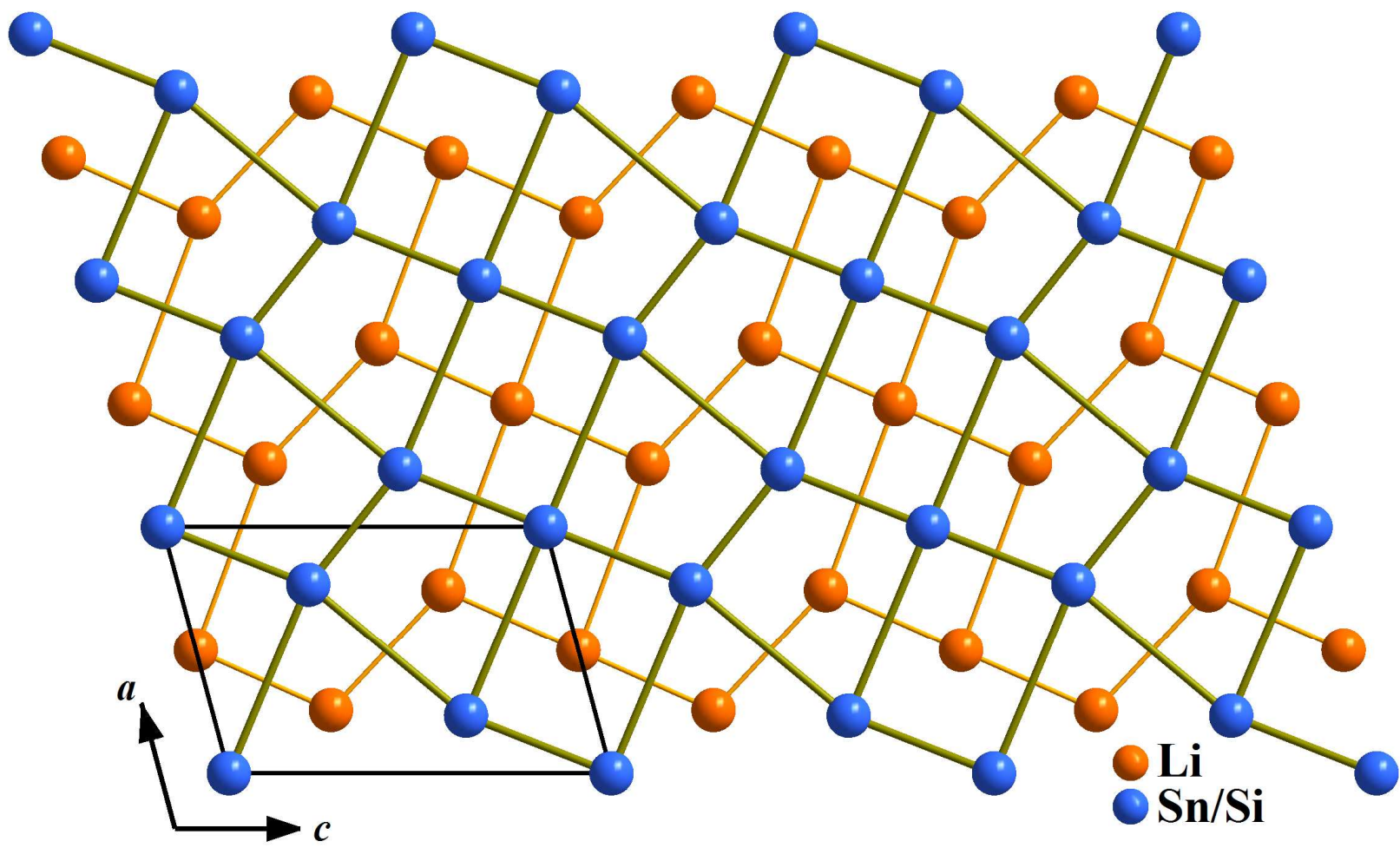

Fig. 6 Atomic layers at $z=0$ and $1 / 2$ in the structure of the $\operatorname{LiSi}_{x} \operatorname{Sn}_{1-x}(x=0-0.2)$ solid solution. 
[3] C.J. Wen, R.A. Huggins, J. Electrochem. Soc. 128 (1981) 1181-1187.

[4] M. Barsoum, H. Tuller, Metall. Mater. Trans. A 19 (1988) 637-644.

[5] W. Gasior, Z. Moser, W. Zakulski, J. Non-Cryst. Solids 205-207 (1996) 379-382.

[6] J. Sangster, C.W. Bale, J. Phase Equilib. 19 (1998) 70-75.

[7] F. Yin, X. Su, Z. Li, J. Wang, J. Alloys Compd. 393 (2005) 105-108.

[8] Z.M. Du, Z.Q. Jiang, C.P. Guo, Z. Metallkd. 97 (2006) 10-16.

[9] D. Li, S. Fürtauer, H. Flandorfer, D.M. Cupid, CALPHAD 47 (2014) 181-195.

[10] U. Frank, W. Müller, H. Schäfer, Z. Naturforsch. B 30 (1975) 6-9.

[11] W. Müller, H. Schäfer, Z. Naturforsch. B 28 (1973) 246-248.

[12] U. Frank, W. Müller, Z. Naturforsch. B 30 (1975) 316-322.

[13] U. Frank, W. Müller, H. Schäfer, Z. Naturforsch. B 30 (1975) 1-5.
[14] W. Müller, Z. Naturforsch. B 29 (1974) 304-307.

[15] D.A. Hansen, L.J. Chang, Acta Crystallogr. B 25 (1969) 2392-2395.

[16] E.I. Gladyshevskii, G.I. Oleksiv, P.I. Krypyakevich, Sov. Phys. Crystallogr. 9 (1964) 269-271.

[17] R. Nesper, H.G. von Schnering, J. Solid State Chem. 70 (1987) 48-57.

[18] G.R. Goward, N.J. Taylor, D.C.S. Souza, L.F. Nazar, J. Alloys Compd. 329 (2001) 82-91.

[19] C. Lupu, J.G. Mao, J.W. Rabalais, A.M. Guloy, J.W. Richardson, Inorg. Chem. 42 (2003) 3765-3771.

[20] M. Zeilinger, T.F. Fässler, Dalton Trans. 43 (2014) 14959-14970.

[21] J. Rodriguez-Carvajal, Phys. B. 192 (1993) 55-69.

[22] O. Azarska, V. Pavlyuk, Pol. J. Chem. 77 (2003) 1027-1031.

[23] M. Zeilinger, D. Benson, U. Häussermann, T.F. Fässler, Chem. Mater. 25 (2013) 1960-1967. 